\title{
An evaluation of GIS tools for generating area cartograms
}

\begin{abstract}
The purpose of this article is to report a study aimed at systematic assessment of the functionality of commercially available software for the automatic generation of area cartograms. The issue of the wide choice of algorithms developed over the years for generating various types of surfaces has also been raised.

Cartograms (called also anamorphic maps) are constructed by changing the surface area of each spatial unit in step with the corresponding value of the mapped thematic variable (area cartogram) or changing accordingly the distance between the preselected focal point and other points on the map (distance cartogram). Depending on the shape of mapping units, the following three types of area cartograms can be distinguished:

- proportional symbol cartograms were the original shapes of mapping units have been replaced with simple geometric shapes such as squares, rectangles or circles (for example, Dorling Circle Cartograms, square cartogram);

- continuous regular cartograms where the shapes of areal units on the map resemble the actual shapes of the mapped units but their boundaries have been geometrized to consist of perpendicular sections;

- continuous irregular cartograms where the shapes of areal units on the map resemble the actual shapes of the mapped units but unit boundaries are not straight lines.

Cartograms can also be constructed to preserve spatial contiguity (continuous cartograms) or not (noncontinuous cartograms), with the latter often preserving the underlying neighborhood relationships to some degree.

While constructing area cartogram, one needs to decide first the type of a surface to be developed, and therefore, the algorithm to be applied. The next step in map construction is the choice of software, where tool selection depends often on the predetermined type of the cartogram.

The study surveyed five programs for the construction of area cartograms - all available free of charge. Each of those software tools was used to generate area cartograms portraying data from the 2010 presidential election in Poland.

Two groups of area cartograms where generated for the purpose of this study: maps of the entire Poland by voivodships, showing the number of valid votes cast for the two presidential candidates in each voivodship, and maps of the Mazowieckie voivodship by county, portraying the number of valid votes cast for the individual candidates in each county.

The subsequent in-depth assessment of surveyed programs took into account eleven criteria including the number of cartogram types that might be developed using each program, availability of tools for the proper legend construction and display, possibility of supplementing the cartogram with complementary choropleth maps, the option for inserting map labels, the type of spatial data that can be used in the software (reference to points, lines, polygons) and so on.

The study has demonstrated that the tool included in the ArcGIS (Cartogram Utility for ArcGIS) best met the survey criteria scoring 9 points. The application Scape Toad placed second ( 7.5 pts.), while MapViewer 7 came third $(6.25$ pts.).

When generating cartograms in the available GIS programs, one should also pay attention to the visual qualities of the generated maps, and in particular, to the resemblance of shapes of spatial units on the map to the their actual geographic boundaries. Since the shape outlines obtained on the map vary depending on the underlying geodetic reference system, the best coordinate system for the mapped area should be selected. However, if such system cannot be used within a given cartogram generating tool, then the obtained cartogram should be exported and refined with some general software package for graphic editing.
\end{abstract}

Keywords: cartogram, area cartograms, GIS 


\section{Cartograms}

Cartograms are maps where depending on the value of the phenomenon, the surface of the particular spatial units (area cartograms sometimes called value-by-area maps) or a distance between a chosen point and selected focal points (distance cartograms) is changed (A. Faliszewska 2011). In the first case the surface area is adjusted to the value of the phenomenon inherent in the unit. In the second case,
The advantage of the area cartograms is a possibility of presenting two types of dataabsolute and relative - simultaneously. The absolute data (e.g. the harvest of grain in quintals) is presented as an areaof the unit and the particular indicator is presented with the color filling ( e.g. number of tractors per 1 ha of crops). It is important to remember about the logical connection of phenomena presented on choropleth map and area cartogram (A. Michalski 2003).

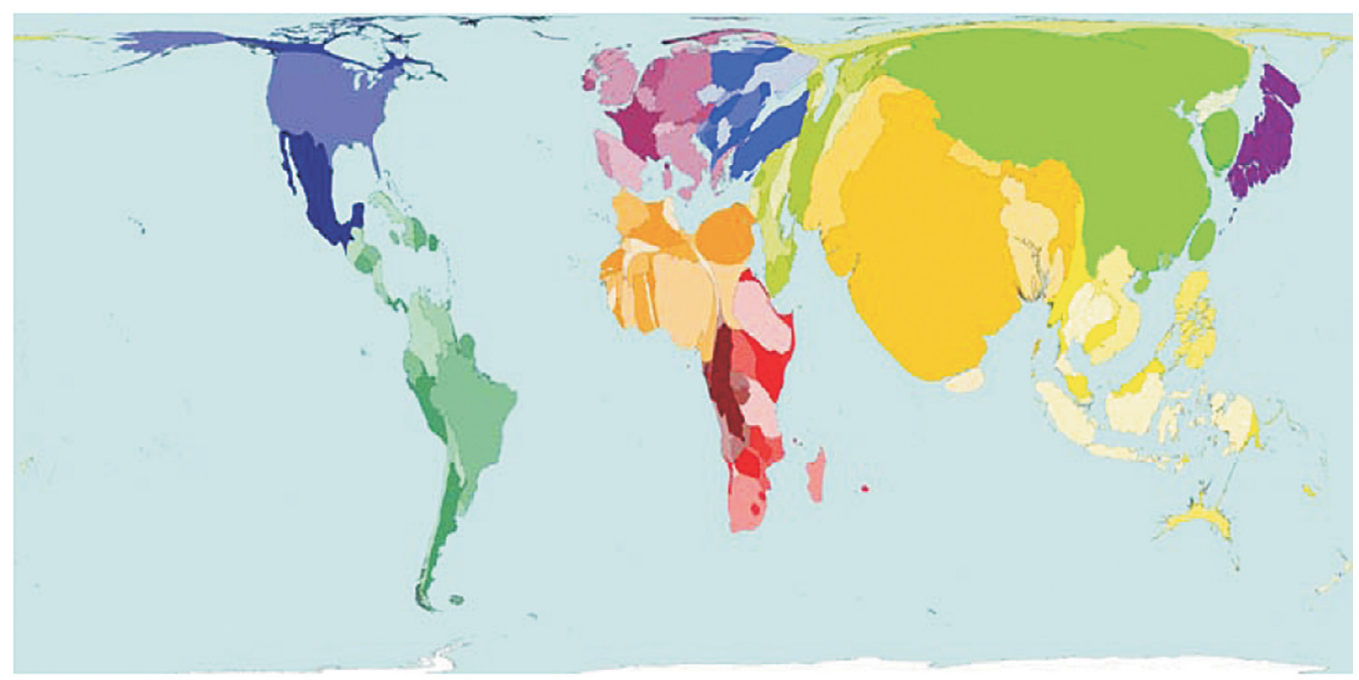

Fig. 1. Area cartogram - worlds population; source: http://www.esri.com/news/arcuser/0110/graphics/cartogram_1-lg.jpg

e.g. time or travel cost can be used as a measure of the distance between the points (B. Dent, J.S. Torguson, T.W. Hodler 2009). With the use of the area cartograms, among others the worlds population by the countries can be presented. On such map, each country will have an area proportional to the number of people (fig. 1). On the other hand the distance cartogram is a good way to present the travel time from the center to the suburbs of London by the underground (fig. 2).

The authors of this article present the ways of cartograms elaboration, available algorithms used for development of this type of cartograms and the software used for this purpose. The distance cartograms are not the subject of interest of this article.
Depending on the shape of the primary field, area cartograms can be divided into three types (A. Markowska 2014, fig. 3):

- proportional symbol cartograms (fig. 3A), were the original shapes of mapping units have been replaced with simple geometric shapes such as squares, rectangles or circles (for example, Dorling Circle Cartograms, square cartogram);

- continuous regular cartograms (fig. 3B), where the shapes of areal units on the map resemble the actual shapes of the mapped units but their boundaries have been geometrized to consist of perpendicular sections;

- continuous irregular cartograms (fig. 3C), where the shapes of areal units on the map 
resemble the actual shapes of the mapped units but unit boundaries are not straight lines.

Area cartograms can also be constructed to preserve spatial contiguity - continuous cartograms or not - noncontinuous cartograms

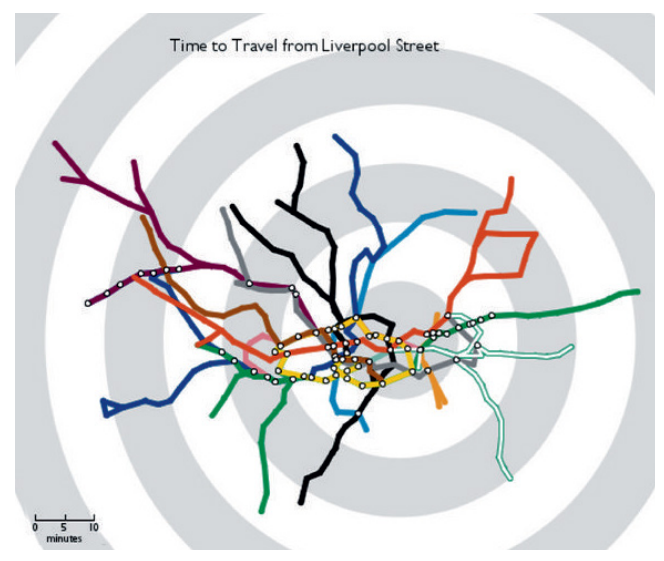

Fig. 2. Distance cartogram - time of journey with the London underground; source: http://www.tom-carden.co.uk/p5/tube_map_travel_times/applet/

(W. Żyszkowska, W. Spallek, D. Borowicz 2012). More specifically noncontinuous cartogram is a kind of cartogram where in order to maintain the full shape of particular units it is necessary to separate the units. For example in order to maintain the shape of all Polish voivodships, they need to be separated, spread apart and their surface should be adjusted to the value of the phenomenon. Reference fields in noncontinuous cartogram may overlap (fig. $4 \mathrm{~A}$ ) or be mutually exclusive (fig. 4B).

\section{Rules of cartograms development}

Area cartograms are a specific form of cartographic presentation, which is often a modification of thematic maps developed with the method of circle maps or choropleth maps (R. Szura 1989). Additionally it is a form of presentation that requires many mathematical calculations and attempts to adjust the surface to the value of the presented phenomenon. Therefore for a better, i.e. faster, visually and essentially correct development of cartograms, various algorithm were developed. The multitude of used algorithms is associated with various problems encountered during the development of cartograms. The most important problems related to development of area cartograms are (M.T. Gastner, M.E.J. Newman 2004):

- keeping proportional surface and shape of the individual units - the proportionality of the unit surface to the value of phenomenon and maintaining their original shape is associated with loosing the continuity of presentation and with violation of the spatial relations (neighborhood);

- failure to keep the shape of units and the whole area - in most cases the area cartograms does not keep the shape of the whole area and the individual units,

- units overlap each other or the lack of continuity of spatial presentation - during generating the cartograms, some units can overlap each other or looses the spatial continuity in solutions where the continuity should be maintained.

During the development of the area cartogram, it is necessary to transform the input (base) map into a new map: $r \rightarrow T(r)$. This can

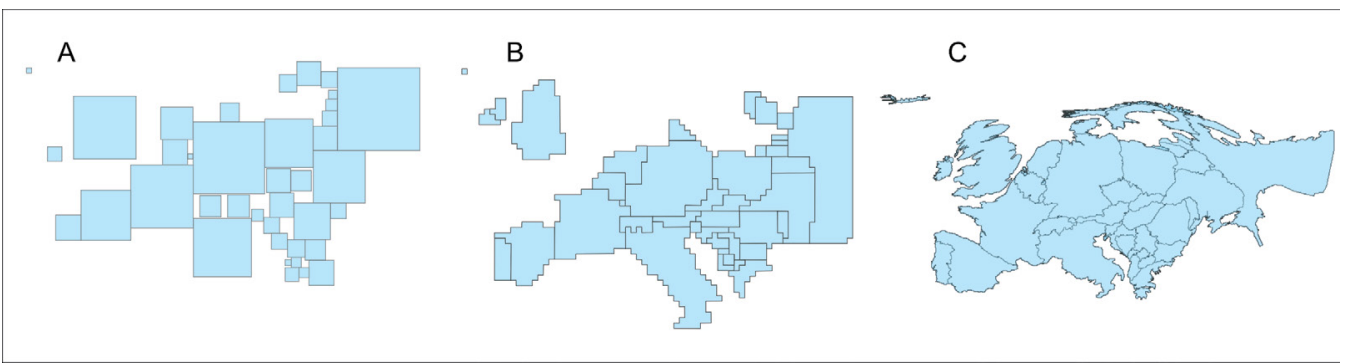

Fig. 3. Cartogram types: A - square cartogram, B - continuous regular cartogram, C - continuous irregular cartogram (Gastner-Newman algorithm); source: own study 
be done according to the formula, defining the transformation, where Jacobian determinant is proportional to a certain, determined density:

$$
\begin{gathered}
\frac{\partial\left(\mathrm{T}_{\mathrm{x}}, \mathrm{T}_{\mathrm{y}}\right)}{\partial(\mathrm{x}, \mathrm{y})} \equiv \frac{\partial \mathrm{T}_{\mathrm{x}}}{\partial \mathrm{x}} \frac{\partial \mathrm{T}_{\mathrm{y}}}{\partial \mathrm{y}}-\frac{\partial \mathrm{T}_{\mathrm{x}}}{\partial \mathrm{y}} \frac{\partial \mathrm{T}_{\mathrm{y}}}{\partial \mathrm{x}}=\frac{\rho(\mathrm{r})}{\bar{\rho}} \\
\text { simplified formula: } \frac{\partial\left(\mathrm{T}_{\mathrm{x}}, \mathrm{T}_{\mathrm{y}}\right)}{\partial(\mathrm{x}, \mathrm{y})}=\frac{\rho(\mathrm{r})}{\bar{\rho}}
\end{gathered}
$$

where:

$\bar{\rho}$-- the average intensity of the phenomenon on the area (M.T. Gastner, M.E.J. Newman 2004).

With the assumption that the average intensity of the phenomenon on a particular area does not change, it is possible to maintain the total area i.e. after the transition to the cartogram, the general total area will not change.

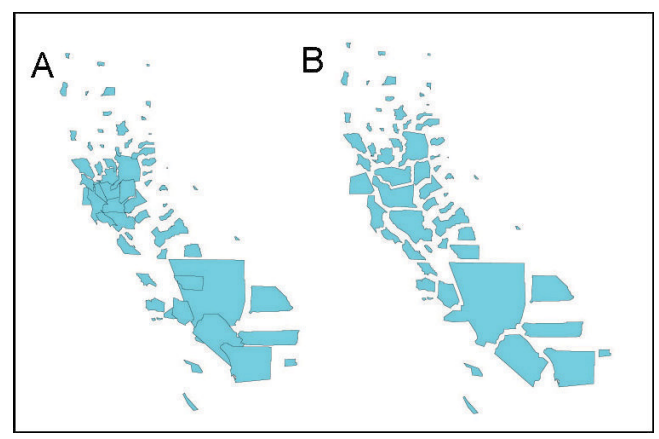

Fig. 4. Noncontinuous area cartogram, A - overlapping, B - nonoverlapping; source: http://www.ncgia. ucsb.edu/projects/Cartogram_Central/types.html

This formula is insufficient for developing the cartogram presentations. Introduction of the second assumption is necessary. Depending on the additional assumption, various algorithms are used to generate the area cartograms. A part of them maintains the shape of individual units (Noncontinuous Area Cartogram), other use proximity and relative position of the individual units (Diffusion-based Method).

The discussed algorithms are used in computer software. The list of available algorithms used in development of area cartograms is available in table 1 (http://en.wikipedia.org/ wiki/Cartogram, access 22.02.2015). They are arranged according to the year of development.
The table consists the information on the author, year, name of the algorithm, type of cartogram and the possibilities of maintaining the units shape.

The most popular and mostly used algorithms according to W. Tobler (2004) are:

- W. Tobler's algorithm from 1973 („RubberMap Method”) and from 1986 („Pseudo-Cartogram"),

- Dougenik-Chrisman-Niemeyer algorithm from 1985 („Rubber Sheet Distortion method”), - J. Olson's algorithm from 1976 („Noncontinuous Area Cartogram"),

- D. Dorling's algorithm from 1990 („Cellular Automation Algorithm” - Dorling D., 1993),

- D. Dorling's algorithm from 1996 - „Circular Cartogram” (Dorling Circle Cartogram),

- House's and Kocmoud's algorithm from 1998 („Continuous Area Cartogram Using the Constraint-based Method"),

- Gastner-Newman's algorithm from 2004 („Diffusion-based Method”).

\section{Development of cartograms in GIS}

On the market there is a large group of software, application or GIS tools, that are used in development of area cartograms (D. House, C. Kocmound, 1998). For the need of the research programs, with the easiest access for the users, were chosen:

- Open GeoDa 1.6.6.,

- MapViewer 7 (demo),

- Cartogram Utility tool, that can be used in ArcGIS (Cartogram Utility for ArcGIS),

- Scape Toad,

- MAPresso.

The above presented software is free (in case of ArcGIS only the tool is free, but the demo or student version of the software can be used).

This software can be divided into two groups:

- applications written especially for cartograms development (MAPresso, Scape Toad),

- overlays or tools for more complex software (Cartogram Utility tools adjusted to ArcGIS software, functions within MapViewer7 - Cartogram Map and Open GeoDa - Cartogram).

This software can also be categorized by the type of cartogram generated from the particular program (A. Faliszewska 2011). This gives the possibility to distinguish the software developing Dorling Circle Cartogram, noncontinuous 
Table 1. The algorithms used in development of area cartograms

\begin{tabular}{|c|c|c|c|c|}
\hline Year & Author & Algorithm & Cartogram type & Keeping units shape \\
\hline 1973 & Tobler & Rubber Map Method & $\begin{array}{l}\text { contiguous irregular } \\
\text { cartogram }\end{array}$ & $\begin{array}{c}\text { No } \\
\text { (shape deformation) }\end{array}$ \\
\hline 1976 & Olson & $\begin{array}{c}\text { Noncontiguous Area } \\
\text { Cartogram (Projector } \\
\text { Method) }\end{array}$ & noncontinuous cartogram ${ }^{1}$ & Yes \\
\hline 1984 & Selvin et al. & $\begin{array}{l}\text { DEMP (Radial Expansion) } \\
\text { Method }\end{array}$ & $\begin{array}{l}\text { continuous irregular } \\
\text { cartogram }\end{array}$ & $\begin{array}{c}\text { No } \\
\text { (shape deformation) }\end{array}$ \\
\hline 1985 & Dougenik et al. & $\begin{array}{c}\text { Rubber Sheet Distortion } \\
\text { Method }\end{array}$ & $\begin{array}{l}\text { continuous irregular } \\
\text { cartogram }\end{array}$ & $\begin{array}{c}\text { No } \\
\text { (shape deformation) }\end{array}$ \\
\hline 1986 & Tobler & Pseudo-Cartogram Method & $\begin{array}{l}\text { continuous irregular } \\
\text { cartogram }\end{array}$ & $\begin{array}{c}\text { No } \\
\text { (shape deformation) }\end{array}$ \\
\hline 1987 & Snyder & $\begin{array}{c}\text { Magnifying Glass } \\
\text { Azimuthal Map Projections }\end{array}$ & $\begin{array}{l}\text { continuous irregular } \\
\text { cartogram }\end{array}$ & $\begin{array}{c}\text { No } \\
\text { (shape deformation) }\end{array}$ \\
\hline 1989 & Cauvin et al. & Piezopleth Maps & $\begin{array}{l}\text { continuous irregular } \\
\text { cartogram }\end{array}$ & $\begin{array}{c}\text { No } \\
\text { (shape deformation) }\end{array}$ \\
\hline 1990 & Torguson & $\begin{array}{l}\text { Interactive Molygon } \\
\text { Zipping Method }\end{array}$ & $\begin{array}{l}\text { continuous irregular } \\
\text { cartogram }\end{array}$ & $\begin{array}{c}\text { No } \\
\text { (shape deformation) }\end{array}$ \\
\hline 1990 & Dorling & $\begin{array}{l}\text { Cellular Automation } \\
\text { Algorithm }\end{array}$ & $\begin{array}{l}\text { continuous irregular } \\
\text { cartogram }\end{array}$ & $\begin{array}{c}\text { No } \\
\text { (shape deformation) }\end{array}$ \\
\hline 1993 & $\begin{array}{l}\text { Gusein-Zade, } \\
\text { Tikunov }\end{array}$ & Line Integral Method & $\begin{array}{l}\text { continuous irregular } \\
\text { cartogram }\end{array}$ & $\begin{array}{c}\text { No } \\
\text { (shape deformation) }\end{array}$ \\
\hline 1996 & Dorling & $\begin{array}{l}\text { Circular Cartogram } \\
\text { (Dorling Cartogram) }\end{array}$ & $\begin{array}{c}\text { proportional symbol } \\
\text { cartogram (Dorling Circle } \\
\text { Cartogram) }\end{array}$ & No (units as circles) \\
\hline 1997 & Sarkar, Brown & Graphical Fisheye Views & $\begin{array}{l}\text { continuous irregular } \\
\text { cartogram) }\end{array}$ & $\begin{array}{c}\text { No } \\
\text { (shape deformation) }\end{array}$ \\
\hline 1997 & $\begin{array}{l}\text { Edelsbrunner, } \\
\text { Waupotitsch }\end{array}$ & $\begin{array}{c}\text { Combinatorial-based } \\
\text { Approach }\end{array}$ & $\begin{array}{l}\text { continuous irregular } \\
\text { cartogram }\end{array}$ & $\begin{array}{c}\text { No } \\
\text { (shape deformation) }\end{array}$ \\
\hline 1998 & $\begin{array}{l}\text { Kocmoud, } \\
\text { House }\end{array}$ & $\begin{array}{c}\text { Continuous Area } \\
\text { Cartogram Using } \\
\text { the Constraint-based } \\
\text { Method }\end{array}$ & $\begin{array}{l}\text { continuous irregular } \\
\text { cartogram }\end{array}$ & $\begin{array}{c}\text { No } \\
\text { (shape deformation) }\end{array}$ \\
\hline 2003 & $\begin{array}{l}\text { Keim, North, } \\
\text { Panse }\end{array}$ & Cartodraw & $\begin{array}{l}\text { continuous irregular } \\
\text { cartogram }\end{array}$ & $\begin{array}{c}\text { No } \\
\text { (shape deformation) }\end{array}$ \\
\hline 2003 & $\begin{array}{l}\text { Keim, North, } \\
\text { Panse }\end{array}$ & HistoScale & $\begin{array}{l}\text { continuous irregular } \\
\text { cartogram }\end{array}$ & $\begin{array}{c}\text { No } \\
\text { (shape deformation) }\end{array}$ \\
\hline 2004 & $\begin{array}{l}\text { Gastner, } \\
\text { Newman }\end{array}$ & Diffusion-based Method & $\begin{array}{l}\text { continuous irregular } \\
\text { cartogram }\end{array}$ & $\begin{array}{c}\text { No } \\
\text { (shape deformation) }\end{array}$ \\
\hline 2004 & Sluga & $\begin{array}{l}\text { Lastna tehnika za izdelavo } \\
\text { anamorfoz }\end{array}$ & $\begin{array}{l}\text { continuous irregular } \\
\text { cartogram }\end{array}$ & $\begin{array}{c}\text { No } \\
\text { (shape deformation) }\end{array}$ \\
\hline 2004 & $\begin{array}{c}\text { Helimann, Keim } \\
\text { et al. }\end{array}$ & RecMap & $\begin{array}{c}\text { proportional symbol } \\
\text { cartogram (rectangular) }\end{array}$ & $\begin{array}{c}\text { No } \\
\text { (units as rectangles) }\end{array}$ \\
\hline 2005 & $\begin{array}{l}\text { Keim, North, } \\
\text { Panse }\end{array}$ & $\begin{array}{l}\text { Medial-axis-based } \\
\text { Cartograms }\end{array}$ & $\begin{array}{l}\text { continuous irregular } \\
\text { cartogram }\end{array}$ & $\begin{array}{c}\text { No } \\
\text { (shape deformation) }\end{array}$ \\
\hline
\end{tabular}

\footnotetext{
1 Noncontiguous cartogram - area cartogram, where to maintain the full shape of particular spatial units it is necessary to separate these units. For example to keep in cartogram the shapes of all Polish voivodeships, they should be spread apart and their surface should be adjusted to the value of the phenomenon (J. Olson 1976).
} 
cartogram or continuous irregular cartogram (Gastner-Newman algorithm or Dougenik-Chrisman-Niemeyer algorithm). The abilities to generate the various types of cartograms are presented in table 2 .

To develop cartograms in analyzed software, the data regarding the presidential elections in Poland in 2010, were used. The data was taken from the http://prezydent2010.pkw.gov.pl website in the form of .xls files. Maps of entire Poland with division into voivodships, were developed as well as the map of Mazovia Voivodship divided into counties. To develop the cartogram itself the absolute data were used, presenting the number of valid votes, votes for Jarosław Kaczyński or the number of votes for Bronisław Komorowski. If the software gave the possibility also the choropleth map was developed. In that case the relative data were used- the percentage support of candidates and the turnout.

The used statistical data regarded the second round of presidential elections in Poland that took place on 4.07.2010. During this round czyński received 7, 919,134 votes, representing $46.99 \%$ of all votes.

For the need of the research the area cartograms of Poland with divisions to voivodeships, were developed, their base was the number of votes for the both candidates in particular voivodship and the map of Mazovia, where the number of valid votes cast for each candidate in a particular county. Maps presented on figure 5 regard the whole Poland divided into voivodeships, and the presented phenomena is the number of valid votes cast for both candidates:

- Open GeoDa 1.6.6. - fig. 5A,

- MapViewer 7 (demo) - fig. 5B and fig. 5C,

- Cartogram Utility for ArcGIS - fig. 5D,

- Scape Toad - fig. 5E,

- MAPresso - fig. 5F.

If the software gave the possibility, the surface of individual units were coloured according to the attendance during the presidential elections (figs. 5D and 5F).

In the majority of software used to generate the maps the .shp files were necessary. Accor-

Table 2. Selected software used for cartograms development

\begin{tabular}{|c|c|c|c|}
\hline & $\begin{array}{c}\text { Proportional symbol cartogram } \\
\text { (Dorling Circle Cartogram) }\end{array}$ & $\begin{array}{c}\text { Noncontinuous } \\
\text { cartogram }\end{array}$ & Continuous cartogram \\
\hline Cartogram Utility for ArcGIS & no & no & Gastner-Newman algorithm \\
\hline MapViewer 7 & yes & yes & no \\
\hline Open GeoDa 0.9.8.14 & yes & no & no \\
\hline MAPresso & yes $^{2}$ & no & $\begin{array}{c}\text { Dougenik-Chrisman-Niemeyer } \\
\text { algorithm }\end{array}$ \\
\hline Scape Toad & no & no & Gastner-Newman algorithm \\
\hline
\end{tabular}

of elections $30,833,924$ Poles had the right to vote, $17,054,690$ voting ballots were issued. There were $17,050,417$ votes given of which $16,853,021$ was important. The turnout was $55.31 \%$ ( the ratio of issued voting ballots to the general number of people entitled to vote). In result of elections Bronisław Komorowski became a president of Poland with the number of $8,933,887$ votes $(53.01 \%)$. Jarosław Ka-

2 The article will not present the Dorling Circle Cartogram developed in MAPresso, because the demo version of the software were not used. ding to that the used data come from the following website http://gadm.org/countryres. That was the contour of Poland divided into voivodeships, and the contour of Mazovia divided into counties. It was impossible to use the Polish data (BDO), because some software are not able to read it. It was related with the use of incompatible with the software settings, Polish coordinates system PUWG 1992 in BDO. The chosen software is foreign, therefore the data in the Polish reference systems are sometimes impossible to read. The problems occurred in Open GeoDa - after entering the Polish data 
the software stopped working. The second problem occurred with ArcGIS. It was possible to add the "Cartogram" tool, load data from the BDO, but after running the tool it was impossi-
- 1 - there is a possibility methodically fully correct.

In some cases different scoring was used e.g. in the question on the number of cartogram
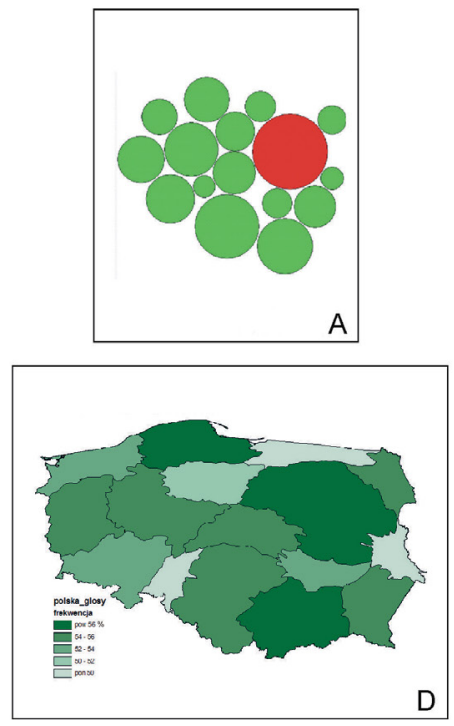
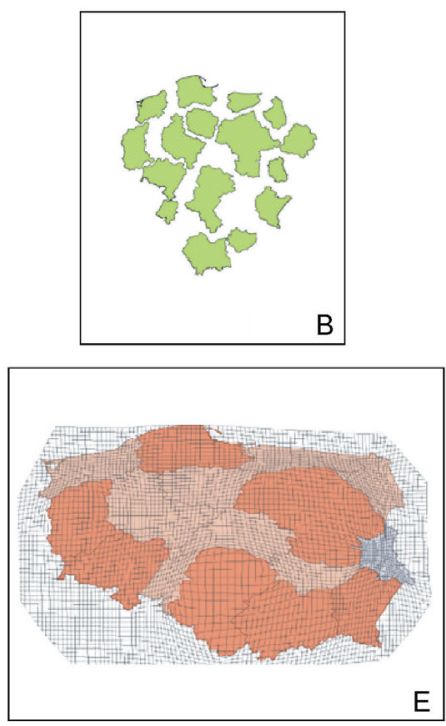

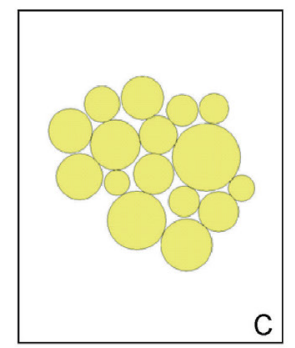

C

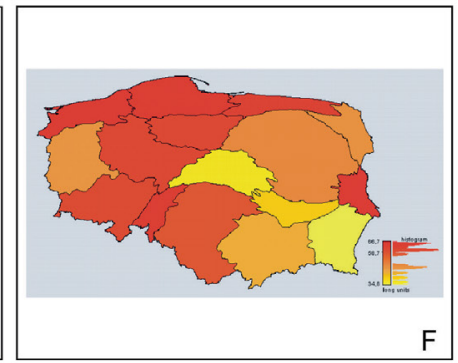

Fig. 5. Maps developed with the use of various software: A - Open GeoDa 1.6.6., B \& C - MapViewer 7, D - Cartogram Utility for ArcGIS, E - Scape Toad, F - MAPresso; source: own study

ble to use this data - the cartogram was not generated. The generalization of units boundaries was not performed while it was no the subject of further research.

\section{Evaluation of software used for developing area cartograms}

Chosen software used for development of area cartograms have been a subject of deep evaluation, that was performed in line with the following points. To compare the software the technical abilities of the software were considered (such as a possibility of saving the developed map or export of data in a vector format) and the essential correctness of developed cartograms (e.g. legend). The software were evaluated in eleven aspects according to the following scoring:

- 0 - there is not such possibility,

- 0.25 - there is a possibility of performing the operations, but it can be methodically incorrect (e.g. legend for choropleth presentation), types possible to develop using the software. All information on scoring are included on subsequent questions. Questions for software assessment:

How many types of cartograms can be developed with the use software? ${ }^{3}$

- for each type, one point was assigned (1 point)

Is it possible to display the cartogram legend?

- if no - 0 pts.,

- if yes, but it is improperly developed- 0.25 pts.,

- if it is possible to display the properly developed legend -1 point

Is it possible to present an additional information on choropleth map?

- if no - 0 pts.,

- if yes but not directly, but after exporting to another software (developed cartogram exported in a vector format to another software is used) -0.5 pts.,

\footnotetext{
${ }^{3}$ By the term „type" was understood: continuous irregular cartogram (without dividend based on the algorithm Dorling Circle Cartogram, noncontinuous area cartogram.
} 
- if development of correct cartogram is possible -1 point

Is it possible to develop a correct choropleth map legend?

- if no -0 pts.,

- if yes, but it is improperly developed 0.25 pts.,

- if a properly developed legend is displayed

-1 point

Is it possible to save and export developed cartogram?

- if no -0 pts.,

- if yes -1 point

Is it possible to export developed cartogram in a vector form

- if no -0 pts.,

- if yes -1 point

Is it possible to turn on the separate spatial units labelling?

- if no -0 pts.,

- if yes -1 point

Is it possible to use the General Geographic Database (BDO)?

- if no -0 pts.,

- if yes -1 point

Is it possible to use data: points, lines, polygons?

- for each data type 0.5 point is assigned

Is support to the software available?

- if no - 0 pts.,

- if yes, but it is available online or to download in a form of an additional file -0.5 pts.,

- if yes and it is built into the software or can be downloaded with the software -1 point

Is the user able to intervene in the settings of process of cartogram generating?

- if no -0 pts.,

- if yes but only partially (few options e.g. Number of grid cells, used to generate cartogram) -0.5 pts.,

- if yes -1 point.

Question no. 1 evaluated the number of cartograms types that can be developed by each software. In the most types of software only one type of cartogram can be developed. Only in MapViewer 7 two types can be developed (Dorling Circle Cartogram and noncontinuous irregular cartogram).

The second question regarded the possibility of cartogram legend development. Only in Scape Toad the essentially proper legend. Therefore only this software received one point. MapViewer received a quarter of point, while the legend can be developed but it is not essentially correct.

The third question was associated with the possibility of choropleth map development. In this case, the maximum number of points was assigned to a software in which the choropleth map could be developed and colour the map units. Such action was possible only in two types of software: Cartogram Utility (ArcGIS) and MAPresso (1 point). The Scape Toad 0,5 point was assigned while after exporting the developed cartogram in a vector format, the choropleth map can be developed with the use of another GIS software.

The fourth question was also related to choropleth map, it regarded the possibility of development the choropleth legend. Only Cartogram Utility for ArcGIS software received one point. In MAPresso the legend can be developed but it is not correct - despite the use of noncontinuous choropleth map, the legend of continuous choropleth map was used.

The fifth and sixth questions are related to the possibilities of saving and exporting (especially in the vector format) the developed cartogram. It seems that these are two very important software options, while they allow for map edition and analysis. The most possibilities related to saving and exporting the map give Cartogram Utility for ArcGIS and Scape Toad (both received one point in each of two questions).

A very important ability of the software used for cartograms development is adding toponyms on maps, and especially names of reference units. The particular cartogram units have modified surfaces and shapes in relation to the geographical image of the unit. Also the shape and the range of the whole area is changed (e.g. loss of spatial continuity). Therefore the labelling function improves the readability of the map. Only Scape Toad does not have this function.

In the eight question the ability to use the Polish General Geographic Database (BDO) in each software type, was examined. Unfortunately only in MapViewer 7 (demo) and Scape Toad BDO can be used. In other there is an incompatibility between BDO and the software coordinate systems.

The next question regarding databases used in software, was related with the spatial reference data - points, lines, polygons. Polygons can be used in all types of software, but only Car- 
Table 3. Comparison of software for area cartograms development

\begin{tabular}{|l|l|c|c|c|c|c|}
\hline \multicolumn{1}{|c|}{ Question } & $\begin{array}{c}\text { Cartogram } \\
\text { Utility } \\
\text { for ArcGIS }\end{array}$ & $\begin{array}{c}\text { MapViewer } \\
\mathbf{7} \text { (demo) }\end{array}$ & $\begin{array}{c}\text { Open } \\
\text { GeoDa } \\
\mathbf{0 . 9 . 8 . 1 4}\end{array}$ & MAPresso & $\begin{array}{c}\text { Scape } \\
\text { Toad }\end{array}$ \\
\hline 1 & $\begin{array}{l}\text { How many types of cartograms can be } \\
\text { developed with the use software? }\end{array}$ & 1 & 2 & 1 & 1 & 1 \\
\hline 2 & $\begin{array}{l}\text { Is it possible to display the cartogram } \\
\text { legend? }\end{array}$ & 0 & 0.25 & 0 & 0 & 1 \\
\hline 3 & $\begin{array}{l}\text { Is it possible to present an additional } \\
\text { information on choropleth map? }\end{array}$ & 1 & 0 & 0 & 1 & 0,5 \\
\hline 4 & $\begin{array}{l}\text { Is it possible to develop a correct } \\
\text { choropleth map legend? }\end{array}$ & 1 & 0 & 0 & 0.25 & 0 \\
\hline 5 & $\begin{array}{l}\text { Is it possible to save and export } \\
\text { developed cartogram? }\end{array}$ & 1 & 0 & 1 & 0 & 1 \\
\hline 6 & $\begin{array}{l}\text { Is it possible to export developed } \\
\text { cartogram in a vector form? }\end{array}$ & 1 & 0 & 0 & 0 & 1 \\
\hline 7 & $\begin{array}{l}\text { Is it possible to turn on the separate } \\
\text { spatial units labelling? }\end{array}$ & 0 & 1 & 1 & 1 & 0 \\
\hline 8 & $\begin{array}{l}\text { Is it possible to use the General } \\
\text { Geographic Database (BDO)? }\end{array}$ & $\mathbf{9}$ & $\mathbf{6 . 2 5}$ & $\mathbf{4 . 5}$ & $\mathbf{4 . 2 5}$ & $\mathbf{7 . 5}$ \\
\hline 9 & $\begin{array}{l}\text { Is it possible to use data: points, lines, } \\
\text { polygons? }\end{array}$ & 1.5 & 0.5 & 0.5 & 0.5 & 0.5 \\
\hline 10 & $\begin{array}{l}\text { Is It is support to the software } \\
\text { available? }\end{array}$ & $\begin{array}{l}\text { Is it the user able to intervene } \\
\text { in the settings of process } \\
\text { of cartogram generating? }\end{array}$ & 1 & 0.5 & 0.5 & 0.5 \\
\hline & Total points & 1 & 0.5 & 0 & 1 \\
\hline
\end{tabular}

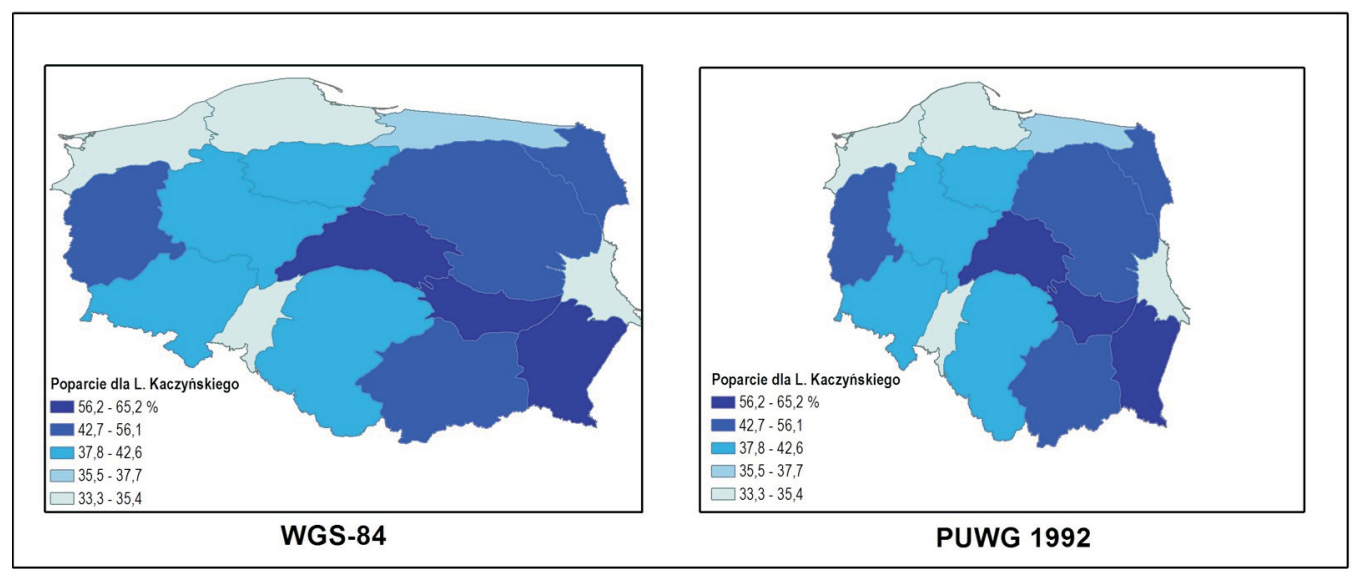

Fig. 6. Improvement of cartograms developed with the use of tools. Usage of ArcGIS to change the reference system of previously developed cartogram; source: own study 
togram Utility for ArcGIS allows to use lines and points that are modified with the polygons layers.

A very important information was a possibility to use software support. It is also important if the help is built in the software or, e.g. possible to download from the website. In the question "Is support to the software available?" the affirmative answer appeared with all programs but only Cartogram Utility for ArcGIS and MapViewer 7 provide this support in .pdf file, that can be downloaded with the software (Cartogram Utility) or built in the software (MapViewer 7). Therefore only these two tools received one point each. In other cases the help is available online.

For the software user also the possibility of interference in parameters in the process of generating cartogram, is important. Scape Toad give the widest range of possibilities, where all options related to the modification of base map can be set manually.

\section{Conclusions}

The results summarized in table 3 show, that the software that meets the best the assumed criteria is the tool to ArcGIS (Cartogram Utility) package, that received 9 points. On the second place the Scape Toad (7.5 pts.) application was ranked and on the third - MapViewer 7 (6.25 pts.).

The difference between the first two is not large. Therefore it is worth to consider if the Cartogram Utility for ArcGIS is more useful to develop the area cartogram. It seems that the use of the Scape Toad software in cartograms development for the area of Poland is more convenient than with Cartogram Utility for ArcGIS due to the possibility to use the data from the Polish General Geographic Database (BDO). The assessment of the developed map is also possible. Scape Toad is a separate

\section{Literature}

Dent, B., Torguson J. S., Hodler T. W., 2009, Cartography: thematic map design, 6th ed., New York: McGraw Hill.

Dorling D., 1993, Map design for census mapping. „The Cartographic Journal", Vol. 30, no. 2, pp. 167-183. software and does not require the purchase the expensive ArcGIS package.

While developing the area cartograms with the use of available GIS software it is important to pay attention for the received maps. It is worth to look at the cartograms presented on the figure 6 , they both consider the same phenomenon, that is the number of valid votes delivered during the presidential elections in 2010. To present this data two reference systems were used - for the first one is WGS-84 system and for the second the Polish Geographic Coordinates System 1992 (PUWG 1992).

It may be noted that the shape of Poland on the first map is strongly latitudinally stretched, especially in comparison with the shape of Poland from the second map. It is related to the used reference system. Such shape is not correct, therefore it is better to use the Polish reference systems, e.g. "1992", while developing the cartograms of Poland. Unfortunately not all software used to generate area cartograms can import the Polish geographical coordinates systems. With the lack of possibility to import the own reference systems, after developing the map in a chosen software, the data can be exported in the .shp format, and next upload received file to another GIS program, that enables the change of reference system. It is also possible to improve the shape without GIS software, but with the use of graphic software, but such procedure is less precise.

Thanks to the presented in the article analysis and evaluation of software used for automatic development of area cartograms, it can be noted that many interesting solutions of this type is available. Before choosing the software it needs to be considered, for what purpose the cartogram will be used and if the map will be develop with the use of one software and if there are the possibilities of graphical and methodical improvement of maps in other programs, graphic as well as GIS software.

Dorling D., 1996, Area cartograms: their use and creation. Department of Geography University of Newcastle upon Tyne, England http://www.qmrg. org.uk/files/2008/11/59-area-cartograms.pdf

Dougenik, J., Nicholas A., Chrisman R., Niemeyer D., 
1985, An algorithm to construct continuous area. "Professional Geographer", Vol. 37, no 1, pp. 75-81

Faliszewska A., 2011, Anamorfoza jako forma prezentacji kartograficznej. Praca magisterska wykonana w Katedrze Kartografii WGiSR UW, Warszawa.

Gastner M.T., Newman M.E.J., 2004, Diffusion-based method for producing density-equalizing maps. "Proceedings of the National Academy of Science" Vol. 101, pp. 7499-7504.

House D., Kocmound C., 1998, Continuous cartogram construction., IEEE Conference on Visualization, pp. 197-204, Research Triangle Park, NC, Oct. 18-23.

Markowska A., 2014, Inne spojrzenie na świat - kartograficzne anamorfozy powierzchniowe, „Edukacja Biologiczna i Środowiskowa”. T. 50, nr 2, pp. 41-52.

Michalski A., 2003, Uwarunkowania konstrukcji map anamorficznych. Praca doktorska, Uniwersytet Przyrodniczy we Wrocławiu.

http://www.fce.vutbr.cz/veda/dk2003texty/pdf/6/rp/ michalski.pdf

Olson J., 1976, Noncontinuous area cartogram. "The Professional Geographer", Vol. 28, no. 4.

Szura R., 1989, Metodyka konstruowania map ana- morficznych. Praca magisterska wykonana w Katedrze Kartografii WGiSR UW, Warszawa.

Tobler W., 1973, A continuous transformation useful for districting. "Annals", New York, Academy of Science, no. 219, pp. 215-220.

Tobler W., 2004, Thirty Five Years of Computer Cartograms. "Annals of the Association of American Geographers" Vol. 94, no. 1, pp. 58-73.

Żyszkowska W., Spallek W., Borowicz D., 2012, Kartografia tematyczna. Warszawa: Wydawnictwo Naukowe PWN.

\section{Internet sources}

http://en.wikipedia.org/wiki/Cartogram [access 22.02. 2015]

http://gadm.org/countryres [ access 22.02.2015]

http://prezydent2010.pkw.gov.pl [access 22.02.2015]

http://www.esri.com/news/arcuser/0110/graphics/ cartogram_1-lg.jpg [ access 22.02.2015]

http://www.ncgia.ucsb.edu/projects/Cartogram Central/types.html [ access 22.02.2015]

http://www.tom-carden.co.uk/p5/tube_map_travel_ times/applet/ [ access 22.02.2015] 